\title{
A firm-level analysis of development banks in Europe
}

Marco Frigerio and Daniela Vandone

Marco Frigerio, Department of Economics, Management and Quantitative Methods, Università degli Studi di Milano, marco.frigerio@unimi.it

Daniela Vandone, Department of Economics, Management and Quantitative Methods, Università degli Studi di Milano, daniela.vandone@unimi.it

Summary: We perform a cross-country firm-level analysis of all development banks headquartered in Europe. The goal is to investigate their financial profile and efficiency characteristics and to shed light on some crucial issues, which may underline their capacity to raise external sources of finance in addition to capital contributions from shareholder governments (e.g. their capital generation and cost efficiency, the quality of their loan portfolio, the composition of their sources of finance). A financial statement analysis of their accounting features is cogent in the light of the relevance attributed by European policy makers to the economic and financial sustainability of development banks, given the key role they have been called to play in the European economy since the 2008 crises. Indeed, although development banks have goals that go beyond profitability, they need to combine their socio-economic goals with conditions of efficiency and profitability, in order to "stand on their own feet" and secure a reasonable level of financial strength and stability. We first map all development banks headquartered in Europe. We then collect financial information within the reference period 2008-2018 for the whole population of development banks. We also split the sample according to size, in order to assess their dimensional heterogeneity.

This study provides policymakers with quantitative information on the economic and financial profile of contemporary promotional financial institutions, which may be valuable in the current debate on their role and relevance in Europe.

$\rightarrow$ JEL classification: G21; O16; L32

Keywords: Development Banks; Ownership; Performance 


\section{AUTHORS}

Marco Frigerio is Research Fellow of Banking and Finance at the Department of Economics, Management and Quantitative methods of the University of Milan. In 2006 he graduated in Economics at the University of Siena. He holds a $\mathrm{PhD}$ in Economics, Markets, Institutions from the IMT Lucca Institute for Advanced Studies. He has worked as researcher at Banca Monte dei Paschi di Siena and UniCredit Group. His research interests are in financial economics, development banks, monetary economics and international finance.

Daniela Vandone is Full Professor of Banking and Finance at the University of Milan. Her research interests are in economics of financial markets and intermediaries, with a focus on microeconomics of financial intermediaries, financial regulation at a European level, financial investments and risk management. She published widely at international level; her research has appeared, among others, in Journal of Economic Psychology, Energy Policy, Quantitative Finance, International Review of Economics and Finance, European Journal of Political Economy, Cambridge University Press. 


\section{Introduction}

In this paper we perform a cross-country firm-level analysis of all development banks headquartered in Europe in order to investigate their financial profile and efficiency characteristics. A financial statement analysis of their accounting features is cogent in the light of the relevance attributed by European policy makers to the economic and financial sustainability of development banks, given the key role they have been called to play in the European economy since the 2008 crises, especially in two fields.

First, development banks are sharing the management of EU financial instruments and implementing financial instruments and programs set up to reverse the low level of investment by EU firms (European Commission, 2014, 2015a; European Parliament, 2016). Indeed, the 2014 Investment Plan for Europe is co-sponsored and managed by the European Investment Bank (EIB) and it is implemented - at national level - by a number of national development banks, such as the Kreditanstalt fuer Wiederaufbau (KfW), the Caisse des Dépôts et Consignations (CDC), the Cassa Depositi e Prestiti (CDP), the Istituto de Credito Oficial (ICO), the Powszechna Kasa Oszczędności Bank Polski (PKO BP). Their role in mobilizing liquidity for micro-enterprises and SMEs has been recently relevant in response to the Covid-19 crisis, given the strong dependency of these small-size firms on bank financing and their inability to directly access the capital market or benefit from the ECB liquidity measures (European Commission 2020).

Second, development banks are assuming a key role in catalyzing long-term private finance towards supporting infrastructure investments and stimulating a response to new global societal challenges in line with the Sustainable Development Goals to be achieved by 2030 , such as climate change and renewable and environmental-friendly 
energy (Foray et al., 2012; Bleda and Del Rio, 2013; European Commission, 2014; European Investment Bank, 2014; Wruuck, 2015; Eslava and Freixas, 2016; Mazzuccato and Penna, 2016; Cingolani 2019; Clò et al., 2020a, 2020b). The scale of the investment required to achieve such goals is well beyond the capacity of the public sector alone, especially given the limited fiscal space available in Member States, and the strict constraints to the direct intervention of states in the economy after the 2008 crises (OECD, 2015). Within this context, development banks play a major role in filling the long-term financing gap by improving the risk-return profile of individual investments, with their preferred creditor status and other risk-sharing mechanisms, therefore creating the conditions to mobilize private financing on a larger scale with blended finance programs, and to work as a catalyzer of institutional investors' participation in infrastructure (OECD, 2017, 2018a, b, c).

The relevance of development banks' activities is such that the European Commission (2015b, p.2) specifies "Member States that do not yet have a national promotional bank may consider setting one up". At the same time, policy makers recommend a special attention to adopt proper policies and best practices to enhance a welfare role while preventing the negative side effects traditionally reported by literature on state-owned banks (Kornai, 1979; Shleifer and Vishny, 1994, 1997; Hart et al., 1997; La Porta et al., 2002; Degl'Innocenti et al., 2020; Frigerio and Vandone 2020).

In particular, in outlining the best practices development banks should follow, the European Commission specifies that "National Promotional Banks prove to work best where they focus on economically viable projects and operate with sufficient profitability (albeit below private operators' cost of equity) to maintain financial soundness without continued capital injections by the government (profits 
mostly being retained to bolster future lending capacity)" (European Commission, 2015b, p.5). Moreover, the relevance of economic and financial sustainability is explicitly stated as a key principle in the statute of many development banks (e.g. CDP, Nordic Investment Bank, NRW.Bank). Indeed, although development banks have goals that go beyond profitability, they need to combine their socio-economic goals with conditions of efficiency and profitability, in order to "stand on their own feet" and secure a reasonable level of financial strength and stability.

Furthermore, strengthening the economics of projects is also crucial to leverage additional financing for blended programs and public-private partnership arrangements, which are attracting, as highlighted above, a growing interest as a way to develop solutions for the delivery of long-term public goals (European Investment Bank, 2014, 2018). The MDB Action Plan to Optimize Balance Sheets explicitly recalls the need for these institutions "to optimize balance sheet in order to increase lending without substantially increasing risks or damaging credit ratings" (Multilateral Development Banks, 2017).

Although the economic issues related to the sustainability of development banks are so central in the EU agenda, what is surprising is that EU scholars have hitherto neglected studies on the balance sheets of these actors. We aim to fill this gap with a financial statement analysis of these understudied institutions. The goal is to provide EU politics and the political science community with quantitative information that are relevant to shed light on some crucial issues (e.g. their capital generation and cost efficiency, the quality of their loan portfolio, the composition of their funding) which may underline their capacity to raise external sources of finance in addition to capital contributions from shareholder governments. 
To our purpose, after mapping all development banks headquartered in Europe, we collect financial information within the reference period 2008-2018 for the whole population of development banks and by splitting the sample according to size, in order to assess for their dimensional heterogeneity.

Overall, results highlight differences across size classes, with larger institutions that generate more capital, have higher cost efficiency and lower credit risk compared to smaller institutions. Large institutions seem therefore to have greater financial soundness, essential for accessing finance on the capital market to supplement the shareholders' equity, which is essential to scale up their activity. Smaller institutions have on average a lower financial leverage ratio, which implies a lower equity multiplier and, consequently, lower capital generation for the same level of profitability. They are also characterized by a higher use of short-term funding, lower cost efficiency, and higher losses due to credit impairment.

The remainder of the paper is organized as follows. Section 2 maps all development banks headquartered in Europe and highlights their geographical distribution and their heterogeneity in terms of size and performances (i.e. capital generation capacity, profitability, cost efficiency). Section 3 empirically analyzes the existing relationship between the different performances of the European development banks in the last decade and their financial structure, funding policies and asset quality. Section 4 concludes. 


\section{Development banks headquartered in Europe}

\subsection{Geographical distribution and heterogeneity by size}

Since there is not a readily available list of all the development banks headquartered in Europe, our analysis of the economic and financial characteristics of these financial intermediaries started from their punctual identification and mapping. In line with Frigerio and Vandone (2020), ${ }^{1}$ we identified 69 development financial institutions based in 20 different countries of the European Union $^{2}$ or supranational by statute.

In terms of distribution by country, the highest number of development financial institutions are found in Germany (18), followed by France (6), Italy and Finland (5). The number of development financial institutions that operate at a supranational level is equal to 9. In the last available year (2018), development banks located in Germany account for 31.9 percent of the European development banks' total assets, followed by supranational development institutions (28.3 percent), institutions located in Italy (16.4 percent), and in France (10.8 percent). This incidence is strongly affected by the different average size of development banks within each country. For example, in Italy there is a large national promotional bank - i.e. Cassa Depositi e Prestiti (whose average

\footnotetext{
${ }^{1}$ The selection of development banks starts by referring to the banks' classification available within the Orbis Bank Focus database, produced by Bureau Van Dijk (BvD). Specifically, the majority of European development banks are identified among those institutions classified as Multi-lateral governmental banks or Specialized governmental credit institutions. Other development banks are identified thanks to the available information on banks' characteristics and their textual descriptions in Orbis Bank Focus. Considerable effort is then devoted to refine the initial selection of European development banks through manual inspection, online research, and a general review of annual reports and publicly available information

${ }^{2}$ Excluding the United Kingdom, in view of the Brexit decision.
} 
total assets amount to approximately 418,347 million euros within the period 20162018) - and some much smaller regional entities (the largest of which is the Banca del Mezzogiorno - Mediocredito Centrale, with about 2,562 million euros of total assets within the same period). A similar situation can be observed in France, where Caisse des Dépôts et Consignations-Groupe Caisse des Dépôts (about 167,685 million euros of total assets) coexists with other national institutions operating on a much lower scale. The case is different in Germany, where KfW (about 488,329 million euros) is accompanied by the presence of some other institutions of considerable size such as NRW.Bank (with about 146,244 million euros of total assets).

Figure 1 shows the kernel density function of $(\log )$ total assets of the European development banks. Total assets by bank are calculated as the average value for the reference period 2008-2018. The distribution suggests a good but not perfect fit to a lognormal. Indeed, the slightly fat tails confirm the significant heterogeneity in terms of size measured by total assets, with a relatively large proportion of development banks operating either on a very large or very small dimensional scale.

In the next sections we examine whether and to what extent the financial soundness of development banks is associated with their size. To this aim, we split our sample of development banks in three groups based on their relative size (as shown in Figure 1). Small development banks are those in the first quartile by total assets, while Large development banks are those in the fourth quartile and Medium-sized development banks are those in the middle (second and third quartile). 


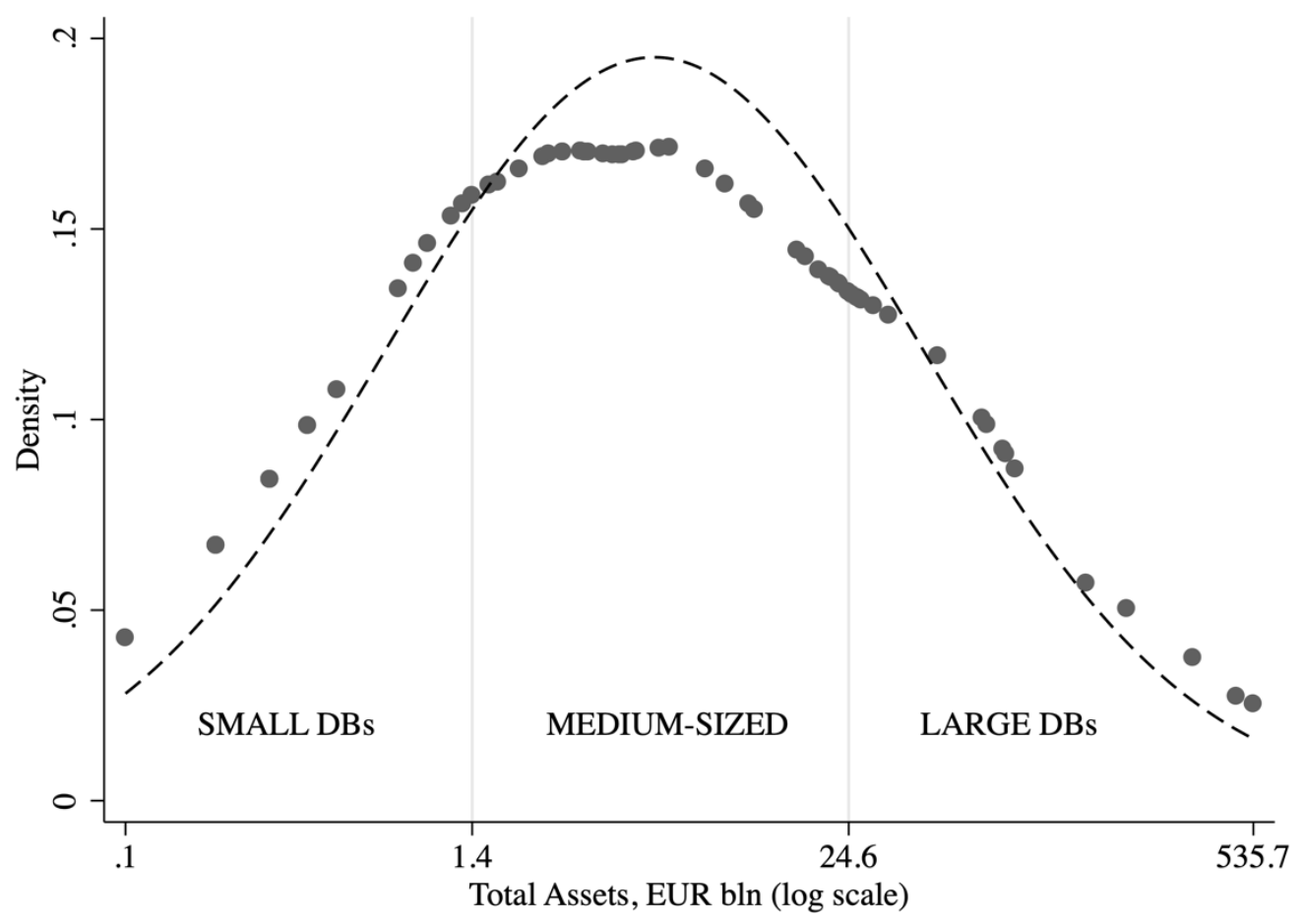

Figure 1. Plot based on the kernel density function of total assets (in natural logarithms) of the European DBs. The dashed line shows a normal density function with the same mean and standard deviation as total assets (in natural logarithms).

\subsection{Profitability and efficiency}

After having mapped European development banks, we analyze their financial performance and capital generation capacity in order to shed light on their soundness and self-sustainability. To this aim, we collected financial information available within the reference period 2008-2018. Specifically, bank balance sheet and income statement data are obtained from the Orbis Bank Focus database (BvD). ${ }^{3}$ In line with extant empirical literature (Micco et al., 2007; Frigerio and Vandone, 2020), for all the main ratios of our interest, we applied a winsorizing procedure that replaces values above the

\footnotetext{
${ }^{3}$ We also recovered historical financial data from the Bankscope database that BvD published until December 2016.
} 
98th percentile and below the 2 nd percentile respectively with the 98 th percentile and the 2 nd percentile. ${ }^{4}$ Mean values for our sample of development banks (and the different size classes) within the reference period 2008-2018 are reported in Table A.1 of the Appendix.

In the period after the global financial crisis development banks generated healthy financial results, recording average levels of ROE around 4.5 percent and a capital generation ratio (i.e. the difference between net income and dividend paid, divided by average total equity) around 3.9 percent, which positively contributed to the banks' own funds in support of long-term financing capacity. Empirical evidence also reveals that the largest institutions achieve better performance (ROE equal to 7 percent) and generate more capital (capital generation ratio equal to 6 percent) than the smallest (3.6 and 3.2 respectively).

In order to better disentangle the main factors contributing to explain the different performances across size classes, the ROE can be usefully decomposed according to the following formula:

$$
R O E=\frac{\text { Profit }}{\text { OperatingProfit }} \cdot \frac{\text { OperatingProfit }}{\text { NetRevenues }} \cdot \frac{\text { NetRevenues }}{\text { TotalAssets }} \cdot \frac{\text { TotalAssets }}{\text { TotalEquity }}
$$

where Profit is the profit (loss) after tax, OperatingProfit is the operating profit before impairment charges, NetRevenues are operating revenues due to the main banks' activities (net interest income, net fee and commission income, and other operating income).

\footnotetext{
${ }^{4}$ We also checked that the main pieces of evidence of our analysis are confirmed using alternative cutoff levels (1/99\% and 5/95\%).
} 
The four factors in the formula represent respectively the profit margin, the operating margin, the asset turnover, and the financial leverage. The boxplots of Figure 2 highlight that these factors actually present a certain degree of heterogeneity across the different size classes.
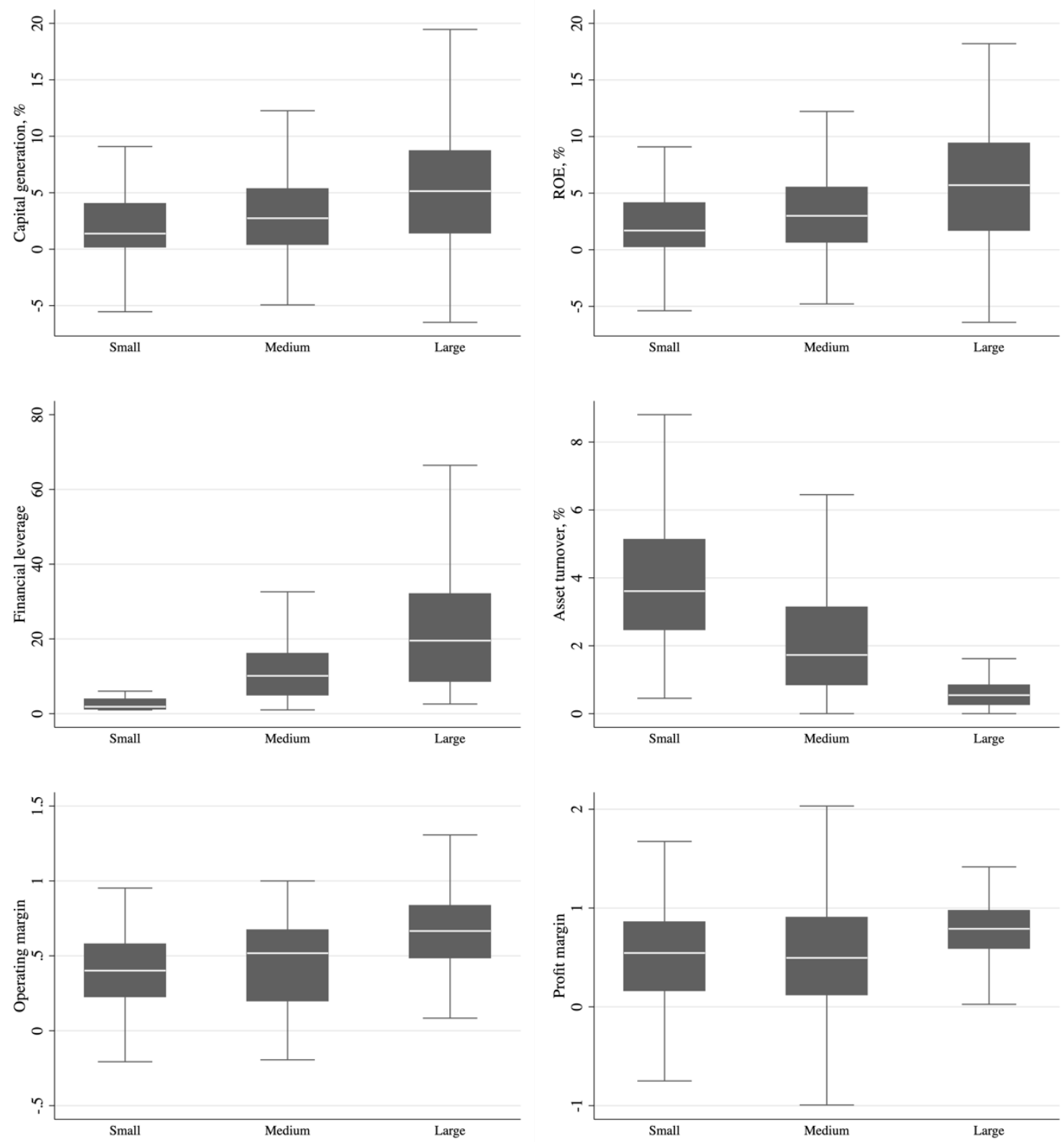

Figure 2. Boxplots of performance ratios in European development banks according to their size. Lower and upper box boundaries identify the 25 th and 75 th percentiles $\left(Z_{[25]}\right.$ and $\left.Z_{[75]}\right)$, respectively. Line inside box identifies the median value $\left(Z_{[50]}\right)$. The lower error line identifies the lower adjacent value, defined as the lowest value $Z_{i}$ such that $Z_{i} \geq Z_{[25]}-1.5^{*}\left(Z_{[75]}-Z_{[25]}\right)$. Similarly, the upper error line identifies the upper adjacent value, defined as the highest value $Z_{i}$ such that $Z_{i} \leq Z_{[75]}+1.5^{*}\left(Z_{[75]}-Z_{[25]}\right)$. Outside values are not plotted. Definitions of financial ratios used in this table are reported in Table A.2 of the Appendix.

Interestingly, Figure 2 shows that small development banks are characterized by higher levels of the asset turnover ratio, i.e. they are able to generate more operating 
revenues from typical banking activities for a same level of total assets. This advantage is partially eroded by lower levels of operating margin and profit margin with respect to large development banks. The latter is mostly influenced by the higher impairment charges (and, in particular, loan loss provisions) experienced by small development banks. The former is due to their lower cost-efficiency (i.e. higher levels of the ratio of operating expenditures to net revenues) and to the low contribution of other operating income from non-banking activities, which on the other hand is very relevant for large development banks. ${ }^{5}$ However, the higher capital generation ratio for large institutions is mainly attributable to much higher average levels of leverage. Indeed, it is just the higher equity multiplier of large development banks (i.e. the higher level of earning assets for a same level of equity), coupled with positive profitability, that enables them to increase their self-financing capacity with respect to small development banks.

\section{Financial statement analysis}

\subsection{Equity multiplier and capital generation capacity}

In Section 2, we have shown that leverage is a key driver for the higher capital generation capacity of large development banks with respect to smaller institutions. Indeed, our empirical analysis reveals a different asset and liability structure across the size classes. The median value of the equity to total assets ratio is around 11.4 percent, which means a total balance sheet of around 9 times the own funds, typically

\footnotetext{
${ }^{5}$ For example, in 2018 the Italian CDP registered revenues from industrial operations around 11,812 million euros, more than five times the net revenues arising from the banking activities. These additional revenues are mainly attributable to de facto control equity investments in non-financial companies such as Fincantieri, Snam, Terna, and Italgas.
} 
represented by profit for the financial year, reserves and capital. However, Figure 3 shows relevant heterogeneity in this equity multiplier across development banks. Indeed, the financial leverage ranges from an average of 5.6 for small development banks to an average of more than 30 for large development banks (respectively 1.7 and 3.4 in the logarithmic scale of the figure). The largest development banks in terms of total assets are just those able to gather more financial resources on the market to supplement the shareholders' equity, which is mainly public in nature. This evidence reminds that development banks typically need to resort to the market if they want to find additional financial resources with respect to those originally allocated by the public shareholder.

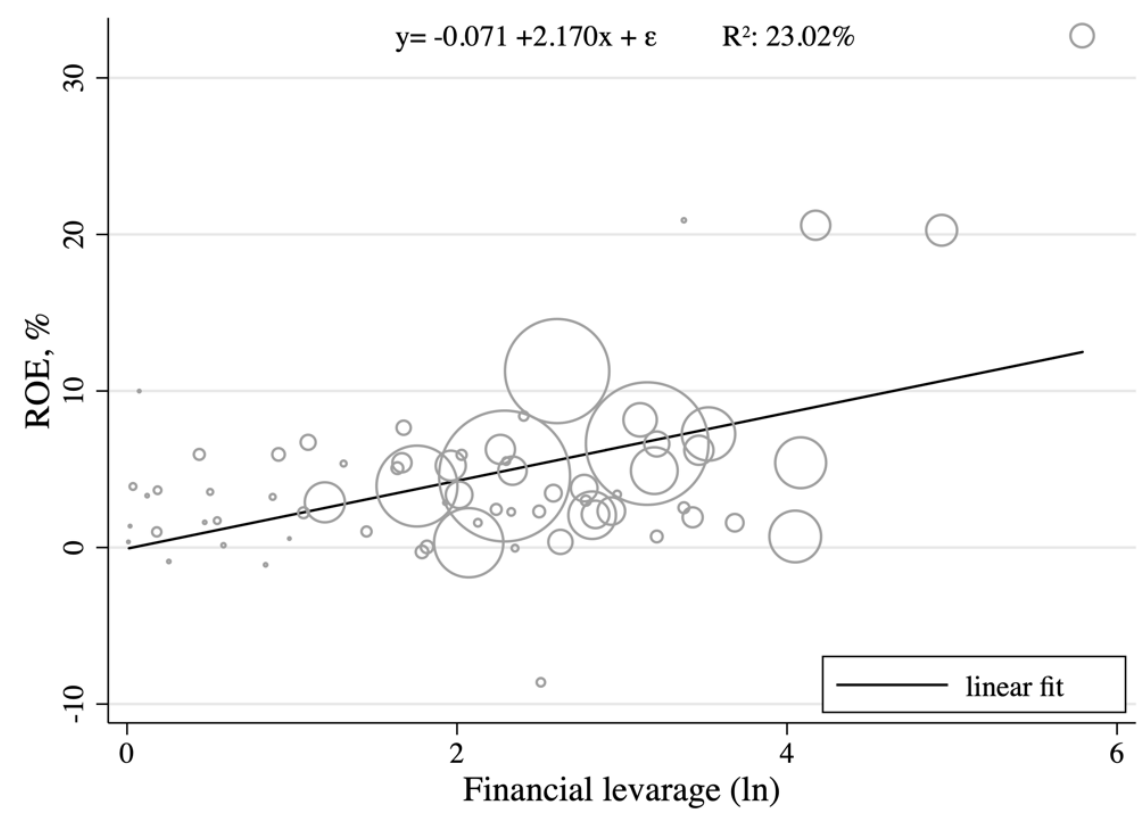

Figure 3. Scatterplot with regression line for ROE (\%) by financial leverage (ln). Bubble size represents total assets (EUR billions). All the measures are obtained as average values by bank for the period 20082018. Definitions of the financial ratios used in this table are reported in Table A.2 of the Appendix.

Interestingly, Figure 3 also confirms that an increase of the financial leverage by one percent is associated with an increase of the ROE by more than 2 percentage points. While a positive contribution to the ROE is expected by definition (as shown in the ROE decomposition formula of Section 2), the empirical evidence reveals that this 
contribution is not more than compensated by potential disadvantages operating concurrently. Although we are aware that bivariate analyses should be taken with due caution since they do not control for potential covariates, this empirical evidence suggests that additional financial resources from the market increase the capital generation capacity of development banks for a same level of asset profitability. In the other way around, the higher profitability of the development bank is expected to improve its ability to draw financial resources from the market.

The attention paid to the financial sustainability of development banks is just legitimized by their dependence on external finance in order to expand the possibilities of intervention to support the real economy. A sound balance sheet and therefore strong credit rating is of outmost relevance to increase these institutions' development exposures given capital resources, as highlighted in several recent reports dealing with the need for development banks to scale up their lending (Multilateral Development Banks, 2017; Settimo, 2017; Munir and Gallagher, 2020). It is worth noting that, in case of government-owned institutions, public guarantees are also relevant to determine the overall rating. However, it has to be stressed that when financial ratios are impaired, public guarantees become the only underlying strength to access financial markets at competitive interest rates, while bringing higher risks of future disbursement by government, and, therefore, public finance.

\subsection{Funding sources, asset utilization and cost-efficiency}

Wholesale funding is the main source of external funding, especially for larger development banks (almost 90 percent of total funding). Indeed, retail funding is 
typically negligible for those development banks that are able to raise funds through bond issuance on the national and international capital markets.

In this context, descriptive statistics reveal that small development banks recur more than large development banks to retail funding and present higher ratios of short term (wholesale or retail) funding to total funding. Actually, long-term funding is almost completely absent in most of the small development banks of our sample. This evidence largely contributes to explain the reason why small development banks tend to finance their activities mainly with equity from their (typically state-owned) shareholders, rather than recurring to external debt.

The high dependence on retail funding is in turn associated with the need for greater capillarity of bank branches and more staff dedicated to the relationship with retail customers. Indeed, development banks that are more dependent on retail funding are those with operational characteristics that are more similar to those of commercial banks. This also implies lower cost-efficiency with respect to institutions that can benefit from long-term wholesale funding to finance their activities. Indeed, Figure 4 shows a positive correlation between the ratio of short-term funding to total funding and both the cost-income ratio and the staff expenses to income ratio. On average, an increase of the short-term funding ratio by 10 percentage point is associated with an increase by almost 2 percentage points of the staff expenses to income ratio and more than 3 percentage points of the cost-income ratio (i.e. staff expenses and other administrative and operating expenses divided by net revenues).

However, the cause-effect relationship also works, at least in part, in the opposite direction. European development banks with the greatest cost inefficiencies are just those relying more on short-term financing, probably due to the difficulties in finding resources with longer maturity. This evidence also contributes to confirm the relevance 
of cost-efficiency and financial credibility for the ability of development banks to access the long-term credit market and to extend their investment capacity.

Figure 4 just confirms that small development banks are those more concentrated on the top right of the graph, that is the area where are located banks with higher dependence on short-term funding and higher incidence of operating expenditures.
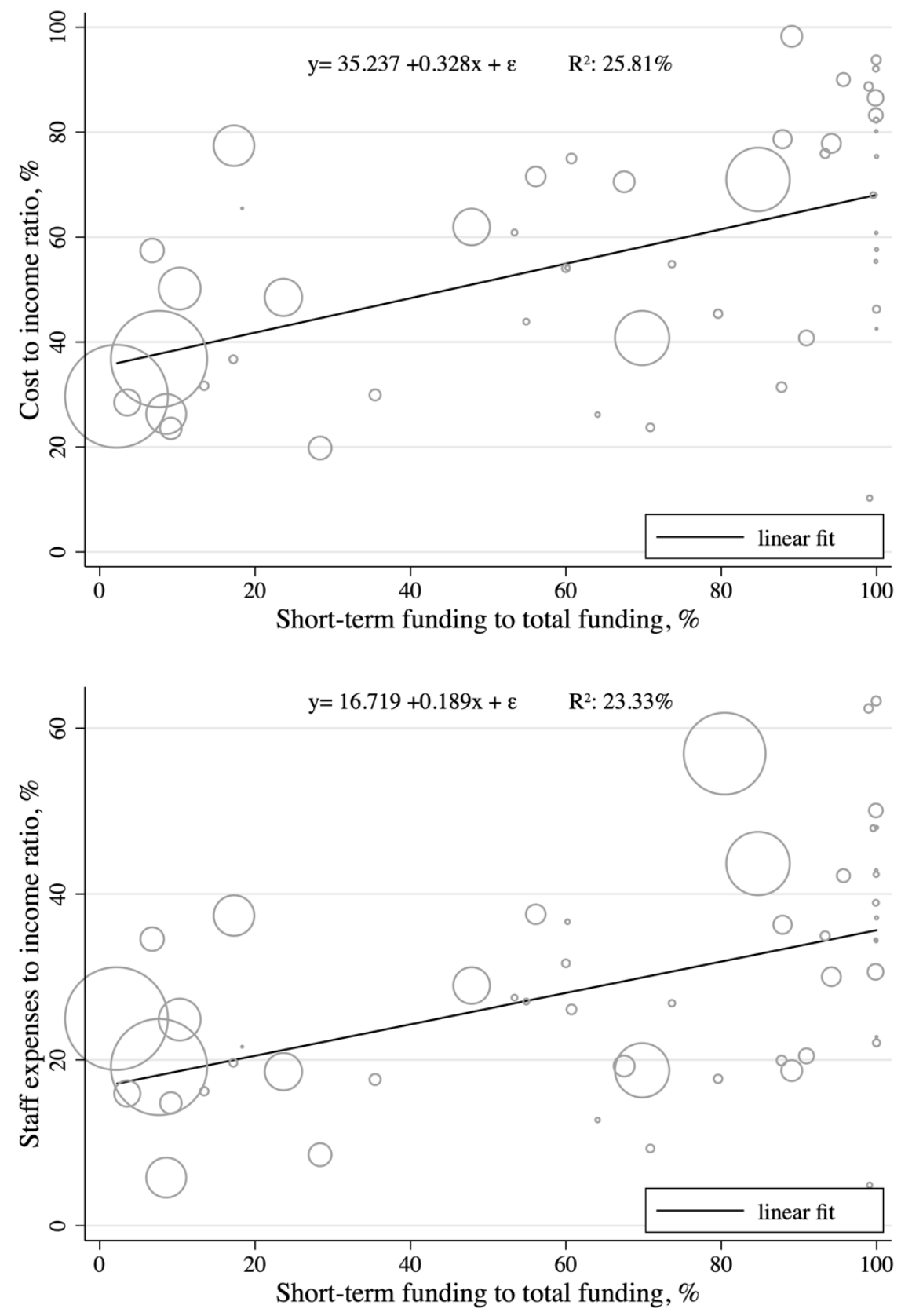

Figure 4. Scatterplot with regression line for Cost to income ratio (\%) and Staff expenses to income ratio (\%) by Short-term funding to total funding (\%). Bubble size represents total assets (EUR bln). All the measures are obtained as average values by bank for the period 2008-2018. Definitions of the financial ratios used in this table are reported in Table A.2 of the Appendix. 


\subsection{Asset quality, impairment losses and pricing policy}

The credit risk is also lower for large institutions. On average, impaired loans are slightly higher than 10 percent of the overall loan portfolio in the whole sample, but they are higher than 16 percent in small development banks while lower than 3 percent in large banks. We acknowledge that this ratio can be highly influenced by the different composition of assets that characterize development banks across the different size classes. However, it certainly contributes to curb the ability of smaller development banks to generate income, due to the higher incidence of net impairment on loans and other advances. Small development banks are able to generate higher operating revenues from typical banking activities (as revealed by the higher levels of the asset turnover ratio) but they also face higher losses due to credit impairment.

Figure 5 confirms the existence of a positive correlation between the net interest margin and the ratio of impaired loans on gross loans as well as the ratio of net impairment charges on average gross loans. On average, an increase of the net interest margin by one percentage point is associated with an increase by 4.5 percentage points of the impaired loans to gross loans ratio and by 1.6 percentage points of the net impairment to gross loans ratio.

Once again, this evidence can also be read in the opposite direction. Development banks that are more exposed to net impairment losses on their loans and receivables are necessarily driven to apply higher interest rates, with a consequent disadvantage for their economy support function. If potential impairment losses are not compensated by a sufficiently profitable pricing policy, development banks put at risk the sustainability of their business and the financial resources that typically come from public 
stakeholders. This risk occurs more frequently among development banks that are more dependent on revenues from typical banking activities, namely smaller development banks.
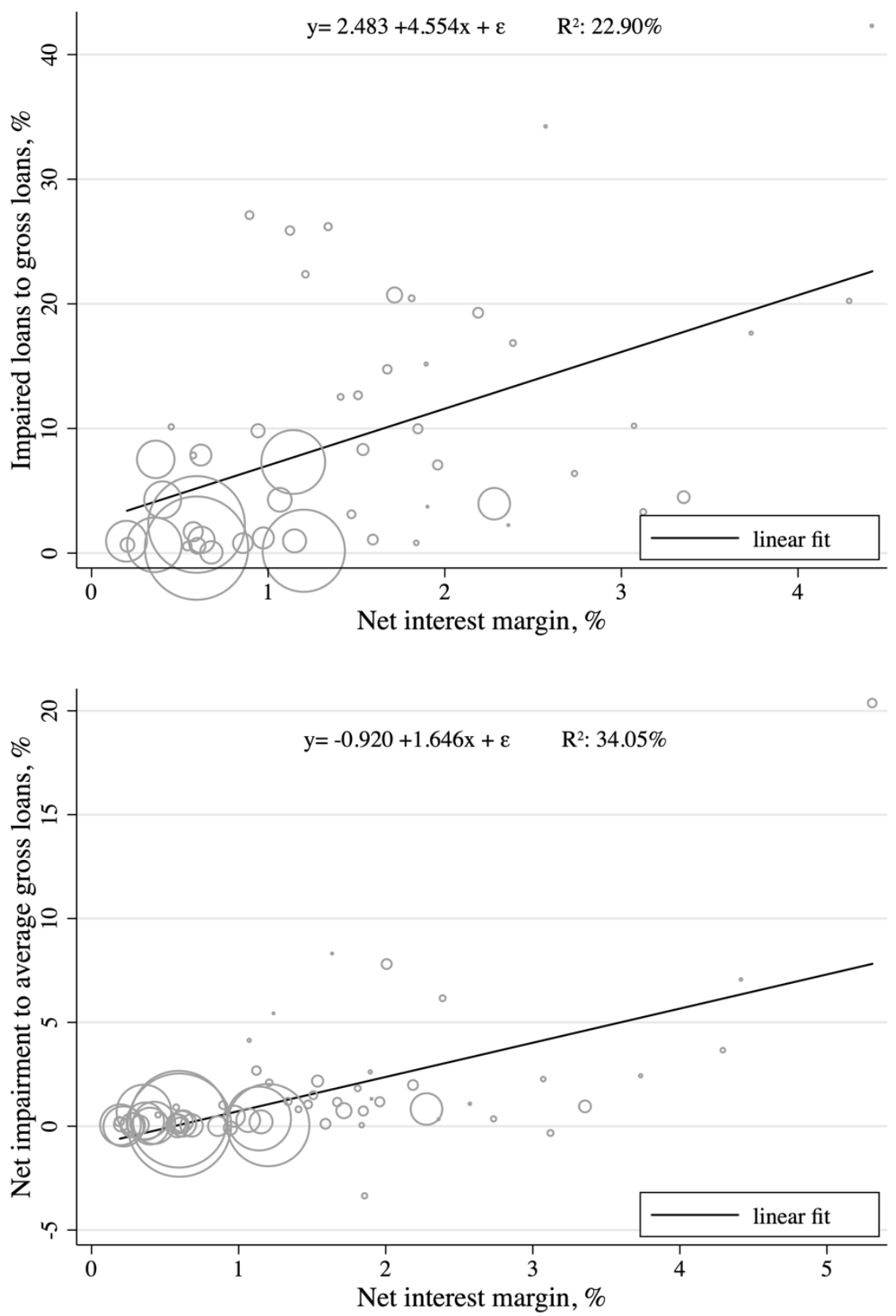

Figure 5. Scatterplot with regression line for Impaired loans to gross loans (\%) and Net impairment charges to average gross loans (\%) by Net interest margin (\%). Bubble size represents total assets (EUR billions). All the measures are obtained as average values by bank for the period 2008-2018. Definitions of the financial ratios used in this table are reported in Table A.2 of the Appendix. 


\section{Conclusions}

In a scenario of limited fiscal space available in Member States and strict constraints to the direct intervention of states in the economy, development banks are increasingly called by European policy makers to sustain growth and investments in EU firms and to mobilize and catalyze long-term commercial finance for infrastructure investments and developmental goals. In asking for their major role, European policy makers are also stressing the need to maintain financial soundness and optimize their balance sheet in order to avoid continued capital injections by governments and to attract further financial resources from private investors.

Although the economic issues related to the sustainability of development banks are so central in the EU agenda, so far there are no empirical studies investigating the balance sheets of these actors. This paper provides policy makers with relevant quantitative information to shed light on some crucial issues, such as their capital generation and cost efficiency, the quality of their loan portfolio, the composition of their sources of finance.

Overall, the composition of the assets and liabilities structure of development banks suggests at least three possible limitations affecting the activity of smaller institutions. First, their lower financial leverage ratio implies a lower equity multiplier and, consequently, lower capital generation for a same level of profitability. Second, small size is also typically associated to a higher use of short-term funding and lower cost efficiency. Finally, small development banks are also more affected by the credit risk that typically characterizes commercial banks. This generates a trade-off between the financial sustainability of small development banks and the pursuit of their mission to support the real economy. For all these reasons, empirical evidence seems to suggest that larger development banks are more able to preserve and increase the financial 
resources made available by governments and their other founders, while still contributing to development in their reference regions.

From the perspective of policy makers, in order to accommodate the growing financial needs of the 2030 Development Agenda and to maximize their development outputs, it is relevant for development banks to leverage the capital contributions from shareholder governments. In fact, the financial soundness of development banks ensures stability and self-sustainability, which - in turn - strengthen their ability to raise external resources to scale up their investment activities and support the real economy.

Our analysis highlights some key drivers of heterogeneity in financial performance across development banks. Future research may further deepen the relationship between the balance sheet structure of development banks and their self-sustainability focusing on the interaction with other determinants, such as differences in their business model, governance policy, and the institutional framework. 


\section{Appendix}

Table A.1: Financial statement indicators

Mean values and standard deviations within the total sample of development banks and by size. See Table A.2 of the Appendix for variable definitions. All ratios are winsorized at the 2 percent and 98 percent levels. Standard deviations in parentheses.

\begin{tabular}{lc|ccc} 
Statistics & All & Small & Medium & Large \\
\hline Capital generation, \% & 3.90 & 3.18 & 3.24 & 5.96 \\
& $(7.50)$ & $(5.76)$ & $(7.45)$ & $(8.72)$ \\
ROE, \% & 4.46 & 3.57 & 3.63 & 6.97 \\
& $(7.39)$ & $(6.42)$ & $(7.02)$ & $(8.42)$ \\
Financial leverage & 18.52 & 5.58 & 17.67 & 33.14 \\
& $(39.57)$ & $(8.49)$ & $(42.27)$ & $(47.49)$ \\
Asset turnover, \% & 2.90 & 5.75 & 2.48 & 0.86 \\
& $(4.04)$ & $(6.34)$ & $(2.37)$ & $(0.99)$ \\
Operating margin & 0.46 & 0.39 & 0.41 & 0.64 \\
& $(0.39)$ & $(0.29)$ & $(0.38)$ & $(0.43)$ \\
Profit margin & 0.53 & 0.47 & 0.47 & 0.72 \\
& $(1.68)$ & $(1.56)$ & $(1.92)$ & $(1.21)$ \\
Cost to income ratio, \% & 53.89 & 61.01 & 58.30 & 37.90 \\
& $(36.68)$ & $(29.23)$ & $(37.83)$ & $(36.71)$ \\
Staff expenses/income, \% & 28.56 & 34.07 & 28.01 & 23.92 \\
& $(18.12)$ & $(17.27)$ & $(15.57)$ & $(21.89)$ \\
Short-term funding/total funding, \% & 63.36 & 84.94 & 72.96 & 32.68 \\
& $(35.61)$ & $(28.32)$ & $(28.72)$ & $(31.46)$ \\
Net interest margin, \% & 1.45 & 2.17 & 1.46 & 0.72 \\
& $(1.47)$ & $(1.75)$ & $(1.45)$ & $(0.62)$ \\
Impaired loans/gross loans, \% & 10.34 & 16.30 & 11.67 & 3.16 \\
& $(12.86)$ & $(16.83)$ & $(12.50)$ & $(4.12)$ \\
Net impairment/average loans, \% & 1.36 & 2.43 & 1.43 & 0.24 \\
& $(4.75)$ & $(6.09)$ & $(5.06)$ & $(0.65)$ \\
\hline Number of bank-year observations & 742 & 192 & 365 & 185 \\
\% by observation number & 100.00 & 25.88 & 49.19 & 4.93 \\
\% by total assets (year 2018) & 100.00 & 0.52 & 9.66 & 89.82 \\
\hline So & & & & \\
& & & & \\
& & &
\end{tabular}

Source: our elaboration on Orbis Bank Focus (BvD) data 
Table A.2: Variables Definitions

All the financial statement indicators are obtained as our elaborations on Orbis Bank Focus (BvD) data.

\begin{tabular}{|c|c|}
\hline Variable & Description \\
\hline Capital Generation & $\begin{array}{l}\text { Retained income (i.e. net income less dividends paid), } \\
\text { divided by average total equity }\end{array}$ \\
\hline ROE & Profit (loss) after tax divided by average total equity \\
\hline Leverage & Average total assets divided by average total equity \\
\hline Asset turnover & $\begin{array}{l}\text { Net revenues divided by average total assets. Net } \\
\text { revenues are the operating revenues related to the main } \\
\text { banks' activities, i.e. net interest income, net fee and } \\
\text { commission income, and other operating income } \\
\text { (including net trading income, net insurance income, } \\
\text { and dividend income) }\end{array}$ \\
\hline Operating margin & $\begin{array}{l}\text { Operating profit before impairment charges divided by } \\
\text { net revenues. Operating profit before impairment } \\
\text { charges is obtained as the sum of operating profit, net } \\
\text { impairment charges on loans \& advances, and net } \\
\text { impairment charges on other assets }\end{array}$ \\
\hline Profit margin & $\begin{array}{l}\text { Profit (loss) after tax divided by operating profit before } \\
\text { impairment charges }\end{array}$ \\
\hline Cost to income ratio & $\begin{array}{l}\text { Total operating expenses divided by net revenues. Total } \\
\text { operating expenses are obtained as the sum of staff } \\
\text { expenses and other administrative and operating } \\
\text { expenses. Net revenues are obtained as the sum of net } \\
\text { interest income, net fee and commission income, and } \\
\text { other operating income (including net trading income, } \\
\text { net insurance income, and dividend income) }\end{array}$ \\
\hline Staff expenses to income ratio & $\begin{array}{l}\text { Staff expenses divided by net revenues. Net revenues } \\
\text { are obtained as the sum of net interest income, net fee } \\
\text { and commission income, and other operating income } \\
\text { (including net trading income, net insurance income, } \\
\text { and dividend income) }\end{array}$ \\
\hline Short-term funding to total funding & $\begin{array}{l}\text { Deposits and short-term funding divided by total } \\
\text { funding. Deposits and short-term funding are the sum of } \\
\text { customer deposits, bank deposits, repos and other short- } \\
\text { term borrowings ( }<1 \text { year). Total funding is the sum of } \\
\text { all deposits, short-term funding and long-term } \\
\text { borrowings ( }>1 \text { year). }\end{array}$ \\
\hline Net interest margin & Net interest income divided by interest earning assets. \\
\hline Impaired loans to gross loans & $\begin{array}{l}\text { Impaired loans divided by average gross customer loans } \\
\text { and advances }\end{array}$ \\
\hline Net impairment to average gross loans & $\begin{array}{l}\text { Net impairment charges on loans and advances divided } \\
\text { by average gross customer loans and advances }\end{array}$ \\
\hline Total assets & Total assets in EUR billions \\
\hline
\end{tabular}




\section{References}

- Bleda, M., and P. Del Rio (2013): The market failure and the systemic failure rationales in technological innovation systems. Research Policy, 42 (5), 10391052 .

- Cingolani, M. (2019): Necessary Public Investment: The Role of Public Banks. International Journal of Political Economy, 48 (3), 275-300.

- Clò, S., M. Frigerio, and D. Vandone (2020a): Contemporary Development Financial Institutions in Europe. In L. Bernier, M. Florio, and P. Bance (Eds.), The Routledge Handbook of State-Owned Enterprises. Routledge Taylor and Francis Group.

- Clò, S., M. Frigerio, and D. Vandone (2020b): Financial support to innovation: the role of European development financial institutions. DISEI working paper, n.10.

- Degl'Innocenti, M., M. Frigerio, and S. Zhou (2020): Development banks and the syndicate structure: Evidence from a world sample. Available at SSRN: https://papers.ssrn.com/sol3/papers.cfm?abstract id=3615477

- Eslava, M., and W. Freixas (2016): Public Development Banks and credit market imperfections. Documentos CIDE n.6.

- European Commission (2014): An Investment Plan for Europe. Communication from the Commission to the European Parliament, the Council, the European Central Bank, the European Economic and Social Committee, the Committee of the Regions and the European Investment Bank. COM(2014)903 final, Brussels.

- European Commission (2015a): Investment dynamics in the euro area since the crisis. Quarterly Report on the Euro Area, 14 (1), 35-43. DG ECFIN.

- European Commission (2015b): Working together for jobs and growth: The role of National Promotional Banks (NPBs) in supporting the Investment Plan for Europe. Communication from the Commission to the European Parliament and the Council, $\operatorname{COM}(2015) 361$ final, Brussels.

- European Commission (2020): Covid-19 and the mobilization of public development banks in the EU. Policy paper n.252, April.

- European Investment Bank (2014): Financial Statement.

- European Investment Bank (2018): Financial Statement. 
- European Parliament (2016): New Financial Instruments and the Role of National Promotional Banks. DG IPOL Study.

- Foray, D., D. C. Mowery, and R. R. Nelson (2012): Public R\&D and societal challenges: what lessons from mission R\&D programs? Research Policy, 41, $1697-1702$.

- Frigerio M., and D. Vandone (2020): European development banks and the political cycle. European Journal of Political Economy, 62, 101852.

- Hart, O., A. Shleifer, and R. W. Vishny (1997): The proper scope of government: theory and an application to prisons. The Quarterly Journal of Economics, 112 (4), 1127-1161.

- Kornai, J. (1979): Resource-constrained versus demand-constrained systems. Econometrica, 47, 801-819.

- La Porta, R., F. Lopez-de-Silanes, and A. Shleifer (2002): Government ownership of banks. The Journal of Finance, 57 (1), 265-301.

- Mazzuccato, M., and C. C. R. Penna (2016): Beyond market failures: The market creating and shaping roles of state investment banks. Journal of Economic Policy Reform, 19 (4), 305-326.

- Micco, A., U. Panizza, and M. Yanez (2007): Bank ownership and performance. Does politics matter? Journal of Banking and Finance, 31 (1), 219-241.

- Multilateral Development Banks (2017): MDB Action Plan to optimize balance sheets. Report.

- Munir, W., and K. P. Gallagher, (2020): Scaling Up for Sustainable Development: Benefits and Costs of Expanding and Optimizing Balance Sheet in the Multilateral Development Banks. Journal of International Development, 32 (2), 222-243.

- OECD (2015): Infrastructure financing instruments and incentives. Report.

- OECD (2017): Breaking silos: actions to develop infrastructure as an asset class and address the information gap. Report.

- OECD (2018a): Capital market instruments to mobilize institutional investors to infrastructure and SME financing in Emerging Market Economies. Report.

- OECD (2018b): The State of blended finance. Report.

- OECD (2018c): Making Blended Finance Work for the Sustainable Development Goals, OECD Publishing, Paris. 
- Settimo, R. (2017). Towards a more efficient use of multilateral development banks' capital. Bank of Italy Occasional Paper, n.393.

- Shleifer, A., and R. W. Vishny (1994): Politicians and firms. Quarterly Journal of Economics ,109 (4), 995-1025.

- Shleifer, A., and R. W. Vishny (1997): A survey of corporate governance. Journal of Finance, 52 (2), 737-783.

- Wruuck, P. (2015). Promoting investment and growth: The role of development banks in Europe. Deutsche Bank Research. 